The Progressive Assault on Laissez Faire 



\section{THE PROGRESSIVE}

ASSAULT ON

\section{LAISSEZ FAIRE}

Robert Hale and the First

Law and Economics Movement

BARBARA H. FRIED

Harvard University Press

Cambridge, Massachusetts

London, England 
Copyright (c) 1998 by the President and Fellows of Harvard College All rights reserved

Printed in the United States of America

Second printing, 2001

First Harvard University Press paperback edition, 2001

Library of Congress Cataloging-in-Publication Data

Fried, Barbara, 1951-

The progressive assault on laissez faire : Robert Hale and the first law and economics movement / Barbara H. Fried.

$$
\text { p. } \quad \mathrm{cm} \text {. }
$$

Includes bibliographical references and index.

ISBN 0-674-77527-9 (cloth)

ISBN 0-674-00698-4 (pbk.)

1. Right of property-United States.

2. Hale, Robert Lee, 1884-1969.

3. Free enterprise-United States.

4. Institutional economics.

5. Neoclassical school of economics.

6. Progressivism (United States).

7. Critical legal studies-United States.

I. Title.

HB701.F75 1998

330. $12^{\prime} 2-\mathrm{dc} 21 \quad 97-39972$ 